\section{Medical Principles and Practice}

Med Princ Pract 2013;22:351-356

DOI: $10.1159 / 000346625$
Received: May 20, 2012

Accepted: December 13, 2012

Published online: February 13, 2013

\title{
Effects of Plum Extract on Skeletal System of Fetal and Newborn Mice
}

\author{
Malihezaman Monsefi Fatemeh Parvin Maryam Farzaneh \\ Department of Biology, College of Sciences, Shiraz University, Shiraz, Iran
}

\section{Key Words}

Animal models · Bone · Bone mineralization · Fetus .

Osteogenesis index $\cdot$ Plum extract $\cdot$ Skeletal system

\begin{abstract}
Objective: To evaluate the effects of Prunus domestica L. extracts on fetuses and neonatal skeletal systems. Materials and Methods: A total of 32 pregnant mice (Mus musculus) received vehicle and plum hydroalcoholic extract at gestational days 1-18 and during the entire gestational period as well as 10 days postpartum, respectively. A total of 30 nonpregnant mice were fed plum hydroalcoholic extract and plum juice extract for 30 days. Bone calcium content and serum concentrations of calcium, magnesium and alkaline phosphatase were measured. The skeletal systems of their fetuses and neonates were stained with Alcian blue and alizarin red $\mathrm{S}$ and the length of femur, tibia, and their ossification center were measured. Results: Crown-rump length of the newborn mice from mothers treated with plum extract (4.61 $\pm 0.25 \mathrm{~mm}$ ) was higher compared to the control group (4.48 $\pm 0.31 \mathrm{~mm}, \mathrm{p}=0.001$ ), and the femur osteogenesis index of newborn mice from mothers treated with plum extract was also higher $(0.87 \pm 0.09)$ compared to the control group $(0.81$ $\pm 0.06, p=0.007)$. Conclusion: The findings showed that pregnant mice treated with plum extract had fetuses and newborn mice with higher osteogenesis index than those of the controls.

Copyright ๑ 2013 S. Karger AG, Basel
\end{abstract}

\begin{tabular}{ll}
\hline KARGER & $\begin{array}{l}\text { ( } 2013 \text { S. Karger AG, Basel } \\
1011-7571 / 13 / 0224-0351 \$ 38.00 / 0\end{array}$ \\
E-Mail karger@karger.com & $\begin{array}{l}\text { This is an Open Access article licensed under the terms of the } \\
\text { www.karger.com/mpp }\end{array}$ \\
& $\begin{array}{l}\text { Creative Commons Attribution-NonCommercial 3.0 Un- } \\
\text { ported license (CC BY-NC) (www.karger.com/OA-license), } \\
\text { applicable to the online version of the article only. Distribu- } \\
\text { tion permitted for non-commercial purposes only. }\end{array}$
\end{tabular}

\section{Introduction}

Plum is a stone fruit tree belonging to the genus Prunus and subgenus Prunus. Findings of recent studies have shown that dried plum, prune (Prunus domestica L.), can be effective in both preventing and reversing bone loss [1-3].

The effects of dried plum on bone loss protection [2, 3 ] and even its reversion were reported in two separate osteopenia models $[4,5]$. Following plum treatment in ovariectomized female rats, bone mineral density (BMD) loss of the femur and lumbar vertebrae were prevented and serum insulin-like growth factor-I (IGF-I) increased $[4,6]$. The elevation of IGF-I was accompanied by an enhanced level of osteogenesis; therefore, plum can improve bone formation. Some studies reported that plum inhibited bone resorption significantly [7]. In a study conducted on animal models, plum impeded BMD loss of the 4 th lumbar vertebra and femurs in orchidectomized rats [3]. The findings of a short-term clinical trial indicated that the consumption of dried plum (100 g/day) by postmenopausal women significantly improved the levels of bone formation indices including serum, total alkaline phosphatase and bone-specific alkaline phosphatase activities, and also IGF-I [8]. Several studies [1-5] have shown that plum can improve bone formation potential in adults but we did not find any published studies designed to investigate the effects of plum extract on cartilage and bone 
Fig. 1. Sketchmatic representation of the experimental procedure.

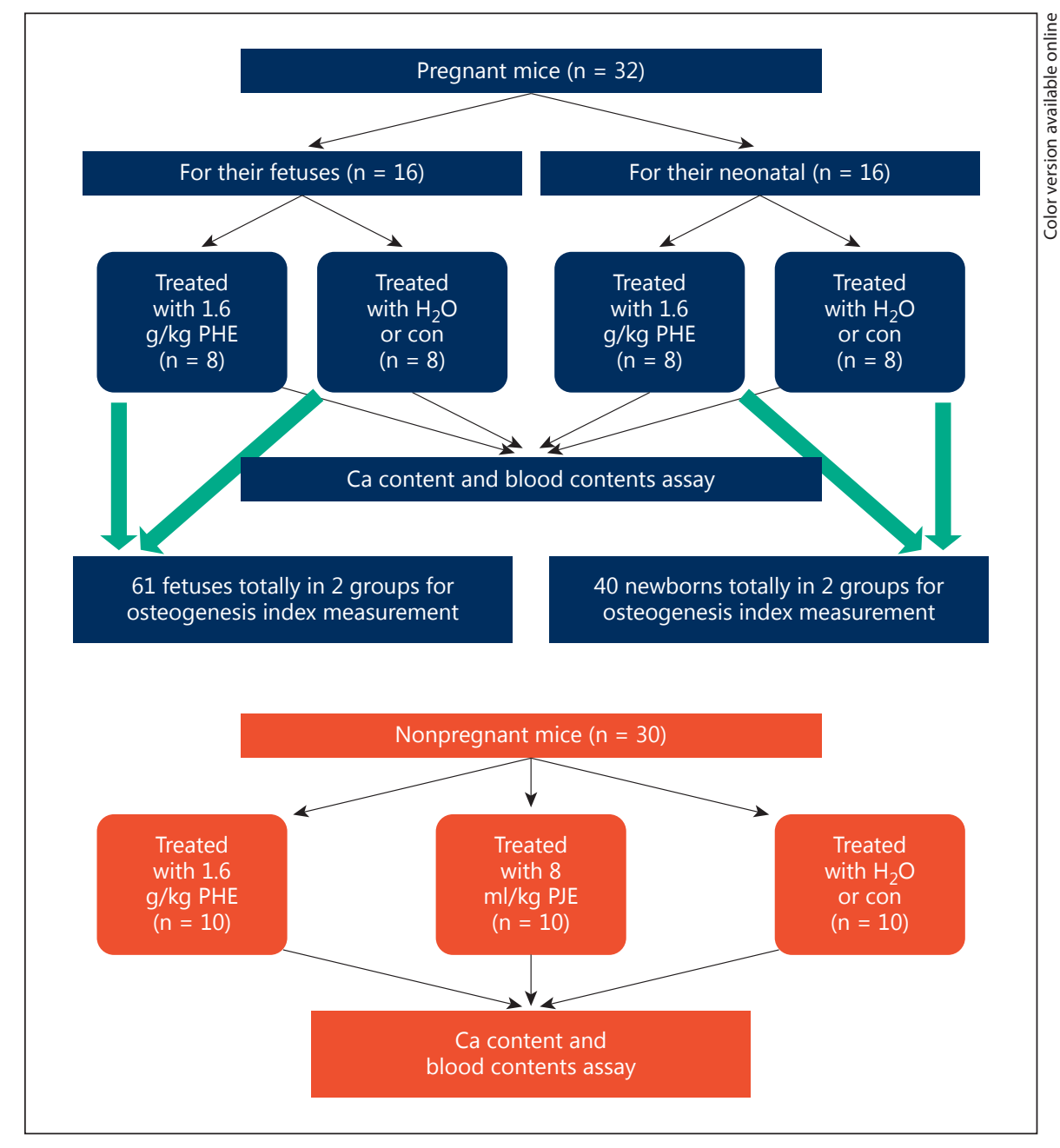

histogenesis under normal conditions, particularly during the embryonic period. We hypothesized that plum extract can improve chondrogenesis and osteogenesis. Since maternal nutrition is an effective factor in pregnancy, the present study was designed to investigate the effects of feeding with plum extracts on the chondrogenic and osteogenic potential of an embryonic and neonatal mouse model.

\section{Methods and Materials}

\section{Extract Preparation}

$P$. domestica L. fruits were collected from Sepidan, a city located in Fars Province, Iran. A total of $150 \mathrm{~g}$ dried plum was extracted from 1,000 g fresh plum. Hydroalcoholic extract was prepared using a percolation method and pureed with a desiccator. Also fruit juice from 1,000 g fresh plum was condensed to $400 \mathrm{ml}$ in a $60^{\circ} \mathrm{C}$ water bath.

\section{Animals and Extract Administrations}

Thirty-two female mice weighing between 30 and $40 \mathrm{~g}$ obtained from the Animal House, Shiraz University of Medical Sciences, Shiraz, Iran were used for the study. The animals were adapted to the laboratory conditions for 2 weeks prior to the beginning of the experiments. Mice were kept at a controlled room temperature of $22-24^{\circ} \mathrm{C}$ with a light:dark cycle of $12: 12 \mathrm{~h}$ (lights on at $09.00 \mathrm{~h}$ and off at $21.00 \mathrm{~h}$ ). The mice had free access to food and tap water. The animal experiments were approved by the Institutional Animal Ethics and Health Committee, Biology Department, Shiraz University. Female mice were caged with male mice and insemination was verified the following morning by checking for the presence of a copulation plug in the vagina. The day the vaginal plug was observed was designated as day 0 of pregnancy (gestation day $0, \mathrm{GD}$ $0)$. Pregnant mice were weighed on the following GDs: 5, 8, 12 and 15. A sketchmatic representation of the experimental procedure is given in figure 1 .

Pregnant mice were divided into two experimental and two control groups $(n=8)$. Mice of the first experimental group were given $1.6 \mathrm{~g} / \mathrm{kg}$ plum hydroalcoholic extract (PHE) orally from GD 1 to 18 . Mice of the second experimental group were treated with 
the same dose for the entire gestational period as well as 10 days postpartum.

For comparison of nonpregnant and pregnant mice, nonpregnant female mice weighing between 30 and $40 \mathrm{~g}$ were divided into experimental and control groups $(\mathrm{n}=10)$ treated with PHE $(1.6 \mathrm{~g} /$ $\mathrm{kg})$. Also the nonpregnant mice $(\mathrm{n}=10)$ were treated with plum juice extract (PJE, $8 \mathrm{ml} / \mathrm{kg}$ ) to compare the effects of these extracts. The extracts were suspended in $0.2 \mathrm{ml}$ distilled water and administered to experimental groups orally by needle gavage for 30 days. The control groups received $0.2 \mathrm{ml}$ distilled water under similar conditions to other groups. Mice were weighed weekly.

\section{Osteogenesis Index Measurement}

Fetuses of the PHE group at GD 19 and newborns at the 10th day postpartum were sacrificed under deep anesthesia. Their crown-rump length and weight were measured. Sixty-one fetuses and 40 newborns were fixed in ethanol 95\%, and then they were skinned and eviscerated. They were defatted in acetone for 3 days at $37^{\circ} \mathrm{C}$ and stained with a mixture of Alcian blue (Merck, Darmstadt, Germany) and alizarin red S (Riedel-de Haën, Germany). The animals were cleared in a series of decreasing concentrations of potassium hydroxide in glycerin and then kept in glycerin. The cartilaginous skeleton was stained with blue dye, and the ossified skeleton with red. The total length of the femur and tibia and the length of their ossified zones were measured under a stereomicroscope equipped with a ruled eyepiece (Zeiss, Mc-80; Jena, Germany). The osteogenesis index was calculated by dividing the ossified length by the total length of each bone (fig. 2).

\section{Calcium Content Measurement}

At the end of the experiment, the pregnant and nonpregnant mice were sacrificed under deep anesthesia and their thighs were dissected out. Then the femurs were removed and cleaned. Bones were dried for $24 \mathrm{~h}$ in a $56^{\circ} \mathrm{C}$ incubator. The dried bones were ashed at $550^{\circ} \mathrm{C}$ for $20 \mathrm{~h}$ in an oven (model 10500, Thermolyne, Dubuque, Iowa, USA). The bone was powdered, and $0.03 \mathrm{~g}$ of the powder was dissolved in $250 \mu \mathrm{HCl}$; this solution was then diluted with $31 \mathrm{ml}$ distilled water. Standard solutions were prepared to contain $0.2 \mathrm{~g} \mathrm{CaCl}_{2}$ in $2 \% \mathrm{HCl}$ (density $720 \mathrm{ppm}$ ). Stock solutions were diluted to $0.03 \mathrm{ppm}$. Calcium $(\mathrm{Ca})$ content was measured using a flame photometer (model 8515, Jenway, Stone, Staffs, UK). The linear fit equation was calculated with Microsoft Excel (Microsoft Corp., Redmond, Wash., USA) as $\mathrm{y}=0.0073 \mathrm{x}+0.0624$ where $\mathrm{y}$ is the bone Ca content and $\mathrm{x}$ is the Ca content of the standard solution.

\section{Serum Contents Assay}

At the end of the experiment, the blood samples of pregnant and nonpregnant mice were taken by heart puncture, then their serum portions were separated after they were centrifuged for 15 $\mathrm{min}$ at 2,000 rpm. Then Ca, magnesium, phosphorus (P) and alkaline phosphatase, blood glucose, triglyceride, cholesterol, highand low-density lipoprotein concentrations of serum were measured using automated clinical analyzer (Biolis 24i, Japan) at the Biochemistry Center of the Research Center of Nemazee Hospital, Shiraz.

\section{Statistical Analysis}

Results are presented as means and standard deviations. Data were analyzed by ANOVA. Tukey's and Scheffé's tests and the least

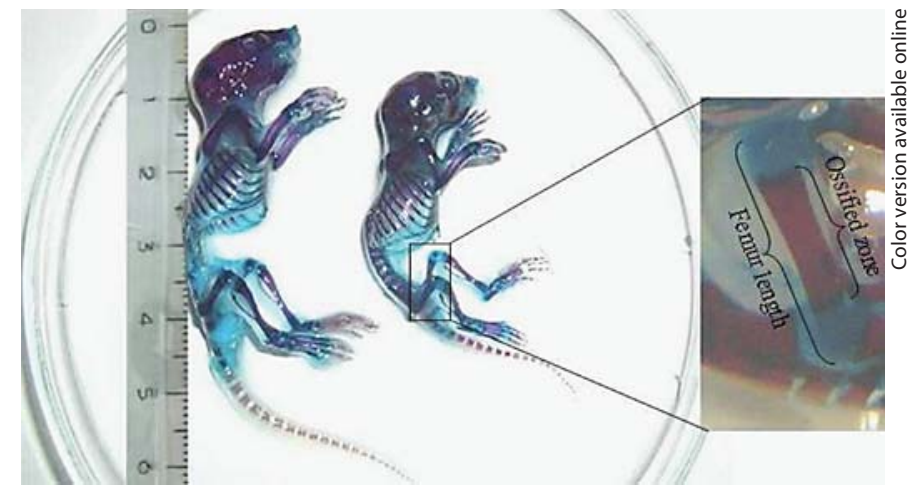

Fig. 2. Effects of plum extracts on cleared newborn skeleton stained with alizarin red $\mathrm{S}$ and Alcian blue. The cartilaginous and bony parts of the skeleton stained blue and red, respectively. Mice treated with PHE (left) were longer than control mice (right).

significant difference method as post hoc tests were also performed. A significance level of 0.05 was set for all statistical analyses.

\section{Results}

The yield (w/w) of dried plum extract was $7.95 \%(\mathrm{~g} / \mathrm{g})$ and that of PJE was $40 \%$ (g/g).

There were no statistically significant differences $(\mathrm{p}=0.92)$ in the body weight of pregnant mice $(51.00 \pm$ $5.68 \mathrm{~g})$ compared to the control group (52.68 $\pm 6.27 \mathrm{~g})$. The weight of breast-feeding mice $(37.25 \pm 4.17 \mathrm{~g})$ did not show a significant difference $(\mathrm{p}=0.62)$ compared to their control group $(39.33 \pm 4.30 \mathrm{~g})$. The body weight of nonpregnant mice in the PHE-treated group $(31.02 \pm 2.82 \mathrm{~g})$ and of PJE-treated mice $(27.88 \pm 1.55 \mathrm{~g})$ did not show any significant difference compared to their control groups ( $\mathrm{p}=0.09$ and $\mathrm{p}=0.87$, respectively).

Fetuses of mice treated with PHE weighed significantly $(1.41 \pm 0.12 \mathrm{~g})$ more than those of the control group $(1.37 \pm 0.12 \mathrm{~g}, \mathrm{p}=0.004)$, and crown-rump length of the newborn mice $(4.61 \pm 0.25 \mathrm{~mm})$ was longer than that of the control group $(4.48 \pm 0.31 \mathrm{~mm}, \mathrm{p}=0.001)$.

The Alcian blue/alizarin red $\mathrm{S}$ staining technique indicated that total femur length and femur ossified length were longer in fetuses of the PHE-treated group ( $\mathrm{p}=$ 0.005 and 0.014 , respectively), whereas tibia length was not significantly different as compared to the control group (table 1). Both the femur and tibia ossified lengths in newborns of PHE-treated mice were higher than those of their control groups $(\mathrm{p}=0.000$ and 0.002 , respectively, 
Table 1. Effects of PHE on tibial and femoral lengths ( $\mathrm{mm}$ ) and osteogenesis index of 19th GD fetuses and 10-day-old newborn mice in different groups

\begin{tabular}{|c|c|c|c|c|c|c|c|}
\hline Groups & & Femoral length & Tibial length & $\begin{array}{l}\text { Femoral ossified } \\
\text { length }\end{array}$ & $\begin{array}{l}\text { Tibial ossified } \\
\text { length }\end{array}$ & $\begin{array}{l}\text { Femoral osteo- } \\
\text { genesis index }\end{array}$ & $\begin{array}{l}\text { Tibial osteo- } \\
\text { genesis index }\end{array}$ \\
\hline \multirow[t]{2}{*}{ Fetuses } & $\operatorname{PHE}(\mathrm{n}=31)$ & $3.55 \pm 0.21^{*}$ & $3.89 \pm 0.15$ & $2.27 \pm 0.14^{*}$ & $2.61 \pm 0.24$ & $0.64 \pm 0.04$ & $0.67 \pm 0.06$ \\
\hline & $\mathrm{CON}(\mathrm{n}=30)$ & $3.42 \pm 0.26$ & $3.82 \pm 0.18$ & $2.16 \pm 0.19$ & $2.54 \pm 0.20$ & $0.63 \pm 0.04$ & $0.66 \pm 0.05$ \\
\hline \multirow[t]{2}{*}{ Newborns } & $\operatorname{PHE}(\mathrm{n}=20)$ & $7.13 \pm 0.71^{*}$ & $9.50 \pm 0.52$ & $6.18 \pm 0.74^{*}$ & $8.19 \pm 0.80^{*}$ & $0.87 \pm 0.09^{*}$ & $0.87 \pm 0.07$ \\
\hline & $\mathrm{CON}(\mathrm{n}=20)$ & $6.57 \pm 0.45$ & $8.49 \pm 0.72$ & $5.29 \pm 0.50$ & $7.43 \pm 0.85$ & $0.81 \pm 0.06$ & $0.87 \pm 0.05$ \\
\hline
\end{tabular}

$\mathrm{CON}=$ Control.

Mean values were significantly different from those of the control group: ${ }^{*} \mathrm{p}<0.05$.

Femoral length of PHE fetuses compared to CON: $p=0.005$; femoral length of PHE newborns compared to CON: $p=0.000$; femoral ossified length of PHE fetuses compared to CON: $\mathrm{p}=0.014$; femoral ossified length of PHE newborns compared to CON: $\mathrm{p}=0.000$; tibial ossified length of PHE newborns compared to CON: $\mathrm{p}=0.002$; femoral osteogenesis index of PHE newborns compared to their CON: $\mathrm{p}=0.007$

Table 2. Effect of PHE on blood contents of $\mathrm{Ca}$, magnesium $(\mathrm{Mg}), \mathrm{P}$, alkaline phosphatase (ALP) and Ca content of bone of mice in different groups

\begin{tabular}{|c|c|c|c|c|c|c|}
\hline Groups & & $\begin{array}{l}\mathrm{Ca} \\
\mathrm{mg} / \mathrm{dl}\end{array}$ & $\begin{array}{l}\text { ALP } \\
\mathrm{U} / 1\end{array}$ & $\begin{array}{l}\mathrm{P} \\
\mathrm{mg} / \mathrm{dl}\end{array}$ & $\begin{array}{l}\mathrm{Mg} \\
\mathrm{mg} / \mathrm{dl}\end{array}$ & $\begin{array}{l}\text { Ca content of bone } \\
\mathrm{mg} / \mathrm{g} \text { dry weight }\end{array}$ \\
\hline \multirow{2}{*}{ Pregnant mice } & PHE $(\mathrm{n}=8)$ & $9.7 \pm 0.50$ & $164.00 \pm 43.59$ & $7.59 \pm 4.13$ & $2.44 \pm 0.24$ & $0.0645 \pm 0.0003$ \\
\hline & $\mathrm{CON}(\mathrm{n}=8)$ & $9.5 \pm 0.51$ & $152.40 \pm 52.09$ & $6.48 \pm 2.10$ & $2.36 \pm 0.13$ & $0.0651 \pm 0.0004$ \\
\hline \multirow[t]{2}{*}{ Breast-feeding mice } & $\operatorname{PHE}(\mathrm{n}=8)$ & $9.63 \pm 0.17$ & $211.50 \pm 42.35$ & $6.20 \pm 1.36$ & $2.83 \pm 0.19$ & $0.0654 \pm 0.0003$ \\
\hline & $\mathrm{CON}(\mathrm{n}=8)$ & $9.46 \pm 0.40$ & $156.20 \pm 31.93$ & $7.08 \pm 2.19$ & $3.02 \pm 0.41$ & $0.0650 \pm 0.0003$ \\
\hline \multirow[t]{3}{*}{ Nonpregnant mice } & $\operatorname{PHE}(\mathrm{n}=10)$ & $9.98 \pm 0.42$ & $166.12 \pm 22.22$ & $9.10 \pm 3.28^{*}$ & $3.10 \pm 0.75$ & $0.0652 \pm 0.0005^{*}$ \\
\hline & $\operatorname{PJE}(\mathrm{n}=10)$ & $10.14 \pm 0.40^{*}$ & $220.75 \pm 87.71$ & $7.16 \pm 1.54$ & $2.98 \pm 0.84$ & $0.0651 \pm 0.0003^{*}$ \\
\hline & $\mathrm{CON}(\mathrm{n}=10)$ & $9.74 \pm 0.44$ & $199.88 \pm 97.97$ & $6.37 \pm 1.93$ & $2.59 \pm 0.27$ & $0.0648 \pm 0.0003$ \\
\hline
\end{tabular}

$\mathrm{CON}=$ Control. Mean values were significantly different from those of the control group: ${ }^{*} \mathrm{p}<0.05$; Ca of PJE compared to CON nonpregnant mice: $\mathrm{p}=0.036$; $\mathrm{P}$ of PHE compared to CON nonpregnant mice: $\mathrm{p}=0.028$; Ca content of bone of PHE compared to CON nonpregnant mice: $\mathrm{p}=0.049$; Ca content of bone of PJE compared to CON nonpregnant mice: $\mathrm{p}=0.020$.

table 1). However, only the femur osteogenesis index of newborns was significantly higher $(p=0.007)$ in comparison to the control groups (table 1).

There were no statistically significant differences in the Ca content of bone in pregnant mice and mice that fed their pups, compared to their controls (table 2). However, the Ca content of bone in nonpregnant mice was significantly higher in the PHE ( $\mathrm{p}=0.049)$ and PJE groups $(\mathrm{p}=0.020)$ than in the control groups (table 2).

Daily dietary supplementation with PHE did not significantly change the levels of serum $\mathrm{Ca}$, alkaline phosphatase, $\mathrm{P}$, magnesium in pregnant and breast-feeding mice, compared to control groups (table 2). The amount of Ca in PJE-treated groups was significantly higher than that in the control group $(\mathrm{p}=0.036)$ whereas high concentrations of $\mathrm{Ca}$ in the PHE-treated group were not significant compared to the control group (table 2). The concentration of $\mathrm{P}$ was significantly higher in PHE-treated mice ( $p=0.028)$; however, the higher concentration of $\mathrm{P}$ in PJE-treated mice compared to the control mice was not statistically significant (table 2). Daily dietary supplementation with PHE did not significantly change the levels of serum glucose, triglyceride, cholesterol, high-density and low-density lipoprotein in pregnant and breastfeeding mice compared to control groups (table 3). Triglyceride and cholesterol concentrations of serum in PJE-treated mice ( $\mathrm{p}=0.001$ and 0.029 , respectively) were significantly higher than in the control group (table 3 ). 
Table 3. Effect of PHE on blood concentration of glucose, triglyceride, cholesterol, high- and low-density lipoproteins (HDL and LDL) of mice in different groups

\begin{tabular}{|c|c|c|c|c|c|c|}
\hline Groups & & $\begin{array}{l}\text { Glucose } \\
\mathrm{mg} / \mathrm{dl}\end{array}$ & $\begin{array}{l}\text { Triglyceride } \\
\mathrm{mg} / \mathrm{dl}\end{array}$ & $\begin{array}{l}\text { Cholesterol } \\
\mathrm{mg} / \mathrm{dl}\end{array}$ & $\begin{array}{l}\mathrm{HDL} \\
\mathrm{mg} / \mathrm{dl}\end{array}$ & $\begin{array}{l}\mathrm{LDL} \\
\mathrm{mg} / \mathrm{dl}\end{array}$ \\
\hline Pregnant mice & PHE $(\mathrm{n}=8)$ & $146.57 \pm 23.96$ & $88.29 \pm 15.50$ & $77.57 \pm 9.03$ & $39.57 \pm 7.04$ & $20.34 \pm 8.00$ \\
\hline \multirow[t]{2}{*}{ Breast-feeding mice } & $\operatorname{PHE}(\mathrm{n}=8)$ & $152.00 \pm 19.08$ & $52.25 \pm 0.96$ & $118.50 \pm 4.04$ & $69.25 \pm 4.27$ & $38.80 \pm 3.73$ \\
\hline & $\mathrm{CON}(\mathrm{n}=8)$ & $138.40 \pm 42.30$ & $67.80 \pm 12.81$ & $120.40 \pm 21.20$ & $66.60 \pm 12.92$ & $40.24 \pm 13.39$ \\
\hline \multirow{2}{*}{ Nonpregnant mice } & $\operatorname{PJE}(n=10)$ & $173.50 \pm 22.15$ & $89.88 \pm 22.89^{*}$ & $105.88 \pm 16.54^{*}$ & $56.38 \pm 10.80$ & $31.53 \pm 9.26$ \\
\hline & $\mathrm{CON}(\mathrm{n}=10)$ & $167.47 \pm 19.94$ & $66.88 \pm 9.82$ & $90.65 \pm 13.44$ & $51.71 \pm 10.22$ & $25.56 \pm 9.66$ \\
\hline
\end{tabular}

$\mathrm{CON}=$ Control. Mean values were significantly different from those of the control group: ${ }^{*} \mathrm{p}<0.05$. Triglyceride concentration of PJE nonpregnant mice compared to CON: $\mathrm{p}=0.001$; cholesterol concentration of PJE nonpregnant mice compared to CON: $\mathrm{p}=0.029$.

\section{Discussion}

According to our data, the femur length of fetuses and newborns in the PHE-treated group, the crown-rump length of newborns in the PHE-treated group, and the bone and serum $\mathrm{Ca}$ and $\mathrm{P}$ contents of nonpregnant mice in the PJE-treated group were significantly increased when compared with those of controls. Despite the greater lengths of femur and tibia in fetuses and newborns of plum extract-treated animals, the Ca contents of bone and serum of their mothers did not change as compared to the control mice. These data confirmed the effects of plum on bone in both mature and immature animals as previously reported [3-6].

It has been reported that nutrient supplements such as soy isoflavones, $\mathrm{Ca}$ and vitamin $\mathrm{D}$ had limited ability to restore bone mass and its structure $[9,10]$, but the boneprotective potential increased significantly in MC3T3-1 (osteoblast-like cells) treated with dried plum extract [4]. This could be due to relatively high amounts of polyphenols $(441 \mathrm{mg} / \mathrm{l})$ in plum juice [11] and plum ethanol extract [12]. Phenolic compounds such as isoflavones and lignans positively influence bone health $[2,13-15]$ and inhibit bone resorption due to their antioxidant and antiinflammatory properties $[7,16]$. Polyphenols also directly stimulate osteoblasts and favorably alter bone formation markers, which would suggest the possibility of anabolic properties $[17,18]$. Rutin, one of the polyphenols of plum juice [11], increased the serum osteocalcin and BMD of estrogen-deficient osteopenic rats [17]. BMD of fetuses treated with isoflavones was increased significantly [19].

Effects of Plum on Bone Loss
Dried plum, plum extract and plum juice are rich in phenolic compounds such as neochlorogenic and chlorogenic acids, which act as antioxidants $[11,12,20,21]$. Antioxidants have been shown to inhibit bone resorption and stimulate bone formation $[22,23]$.

The $\mathrm{pH}$ buffering capacity of potassium enhanced bone health and decreased bone resorption [24, 25]. Potassium also increased bone formation markers such as serum IGF-I in postmenopausal women [25]. A third component of plum known to play a role in bone metabolism is vitamin $\mathrm{K}[11,12]$. Vitamin $\mathrm{K}$ facilitates the carboxylation of proteins such as osteocalcin and consequently is involved in bone matrix synthesis [26]. Vitamin $\mathrm{K}$ increases serum osteocalcin and lumbar bone mass in children that were treated with long-term glucocorticoid [27]. Vitamin K directly stimulates osteoblast differentiation and inhibits osteoclastogenesis in vitro [26]. Although supplemental potassium, vitamin $\mathrm{K}$ and individual polyphenols such as rutin positively influence bone metabolism, there are no reports to show the effects of these components together, as in plum components, on bone. Ovariectomized female rats treated with 5 or $25 \%$ dried plum did not show bone loss induced by gonadal hormone deficiency of femur, vertebral column and reduction in whole-body BMD. Increased level of IGF-I in rats treated with dried plum and its extract enhanced trabecular bone volume $[6,28,29]$. The tibial osteogenesis index in fetuses and newborns did not reveal significant differences compared to the control mice. This may be due to its developmental stage and ossification center formation, which is later in the tibia than in the femur. 
According to our data, the other serum components such as alkaline phosphatase were not altered in plum extract-treated mice as compared to the control groups. There were not any alterations in the alkaline phosphatase levels in rats following a 90-day period of vitamin $\mathrm{K}$ administration [5] and dried plum treatment [6]. Therefore, plum extract did not appear to alter bone mineralization, however, it influenced osteoblast number and had optimal effects on bone metabolism based on both bone resorption and formation [3]. Higher concentrations of $\mathrm{Ca}$ and $\mathrm{P}$ in PJE- and PHE-treated mice, respectively, may be due to the different components of these extracts.

\section{Conclusion}

The findings showed that plum extract increased femoral and tibial lengths, bone and serum Ca contents of adult nonpregnant animals and osteogenesis indices of fetuses and newborns of pregnant mice. Further investigation is needed to clarify the exact influence of plum on bone metabolism and its potential mechanism.

\section{Acknowledgment}

The present study was financially supported by the Vice-Chancellor for Research of Shiraz University. The authors are thankful to Mrs. Arasteh for extract preparation.

\section{References}

1 Hooshmand SH, Arjmandi B: Dried plum, an emerging functional food that may effectively improve bone health. Ageing Res Rev 2009;8: 122-127.

-2 Arjmandi BH, Khalil DA, Smith BJ, et al: Soy protein has a greater effect on bone in postmenopausal women not on hormone replacement therapy, as evidenced by reducing bone resorption and urinary calcium excretion. J Clin Endocrinol Metab 2003;88:1048-1054.

-3 Franklin M, Bu SY, Lerner MR, et al: Dried plum prevents bone loss in a male osteoporosis model via IGF-I and the RANK pathway. Bone 2006;39:1331-1342.

4 Hooshmand S, Chai SC, Arjmandi BH: Dried plum polyphenols increase insulin-like growth factor (IGF-I) production in osteoblast-like cells. J Bone Miner Res 2008; 23:SU002.

5 Bu SY, Lucas EA, Franklin M, et al: Comparison of dried plum supplementation and intermittent PTH in restoring bone in osteopenic orchidectomized rats. Osteoporos Int 2007; 18:931-942.

6 Arjmandi BH, Lucas EA, Juma S, et al: Dried plum prevent ovariectomy-induced bone loss in rats. JANA 2001;4:50-56.

7 Mühlbauer RC, Lozano A, Reinli A, et al: Various selected vegetables, fruits, mushrooms and red wine residue inhibit bone resorption in rats. J Nutr 2003;133:3592-3597.

8 Arjmandi BH, Lucas EA, Smith BJ, et al: Dried plums improve indices of bone formation in postmenopausal women. J Womens Health Gend Based Med 2002;11:61-68.

-9 Khalil DA, Lucas EA, Juma S, et al: Soy protein supplementation increase serum insulinlike growth factor-I in young and old men but does not affect markers of bone metabolism. J Nutr 2002;132:2605-2608.

10 Khalil DA, Lucas EA, Smith BJ, et al: Soy isoflavones may protect against orchidectomyinduced bone loss in aged male rats. Calcif Tissue Int 2005;76:56-62.
11 Diane M, Barrett LS, Hosahalli R: Processing Fruit, 2nd ed. Boca Raton, CRC Press, 2005, pp 513-528.

12 Se-Na K, Mee-Ree K, Soo-Muk C, et al: Antioxidant activities and determination of phenolic compounds isolated from oriental plums (Soldam, Oishiwase and Formosa). Nutr Res Pract 2012;6:277-285.

13 Arjmandi BH, Alekel L, Hollis BW, et al: Dietary soybean protein prevents bone loss in an ovariectomized rat model of osteoporosis. J Nutr 1996;126:161-167.

14 Arjmandi BH, Birnbaum R, Goyal NV, et al: Bone-sparing effect of soy protein in ovarian hormone-deficient rats is related to its isoflavone content. Am J Clin Nutr 1998;68:1364S1368 S.

15 Arjmandi BH, Getlinger MJ, Goyal NV, et al: Role of soy protein with normal or reduced isoflavone content in reversing bone loss induced by ovarian hormone deficiency in rats. Am J Clin Nutr 1998;68:1358S-1363S.

16 Woo JT, Nakagawa H, Notoya M, et al: Quercetin suppresses bone resorption by inhibiting the differentiation and activation of osteoclasts. Biol Pharm Bull 2004;27:504-509.

17 Horcajada-Molteni MN, Crespy V, Coxam V, et al: Rutin inhibits ovariectomy-induced osteopenia in rats. J Bone Miner Res 2000;15: 2251-2258.

18 Mizutani K, Ikeda K, Kawai Y, et al: Resveratrol stimulates the proliferation and differentiation of osteoblastic MC3T3-E1 cells. Biochem Biophys Res Commun 1998;253:859863.

19 Mardon J, Mathey J, Kati-Coulibaly S, et al: Influence of lifelong soy isoflavones consumption on bone mass in the rat. Exp Biol Med 2008;233:229-237.

20 Nakatani N, Kayano S, Kikuzaki H, et al: Identification, quantitative determination, and antioxidative activities of chlorogenic acid isomers in prune (Prunus domestica L.). J Agric Food Chem 2000;48:5512-5516.
1 Kayano S, Yamada NF, Suzuki T, et al: Quantitative evaluation of antioxidant components in prunes (Prunus domestica L.). J Agric Food Chem 2003;51:1480-1485.

22 Garrett IR, Boyce BF, Oreffo RO, et al: Oxygen-derived free radicals stimulate osteoclastic bone resorption in rodent bone in vitro and in vivo. J Clin Invest 1990;85:632-639.

23 Basu S, Michaelsson K, Olofsson H, et al: Association between oxidative stress and bone mineral density. Biochem Biophys Res Commun 2001;288:275-279.

24 Macdonald HM, New SA, Fraser WD, et al: Low dietary potassium intakes and high dietary estimates of net endogenous acid production are associated with low bone mineral density in premenopausal women and increased markers of bone resorption in postmenopausal women. Am J Clin Nutr 2005;81:923-933.

25 Sebastian A, Harris ST, Ottaway JH, et al: Improved mineral balance and skeletal metabolism in postmenopausal women treated with potassium bicarbonate. N Engl J Med 1994; 330:1776-1781.

26 Koshihara Y, Hoshi K, Okawara R, et al: Vitamin K stimulates osteoblastogenesis and inhibits osteoclastogenesis in human bone marrow cell culture. J Endocrinol 2003;176:339-348.

-27 Inoue T, Sugiyama T, Matsubara T, et al: Inverse correlation between the changes of lumbar bone mineral density and serum undercarboxylated osteocalcin after vitamin K-2 (menatetrenone) treatment in children treated with glucocorticoid and alfacalcidol. Endocr J 2001;48:11-18.

28 Kamkar L, Hooshmand S, Soliman A, et al: Polyphenol extract from dried plum dosedependently increase nodule formation in MC3T3-E1 osteoblast-like cells. J Bone Miner Res 2005;20:SU246.

29 Kamkar L, Hooshmand S, Lucas EA, et al: Influence of dried plum polyphenol extract on bone formation and inflammation. J Bone Miner Res 2006;21:M199. 